\title{
特＼cjkstart集〕「免疫チェックポイント阻害薬はがんの治療の未来をどう変えるか」
}

\author{
ニボルマブの作用機序，効果，副作用と \\ 日本大学医学部附属板橋病院皮膚科での使用経験
}

\author{
伊崎 聡志＼cjkstart葉山 惟大 照井 正 \\ 日本大学医学部皮膚科学系皮虐科学分野
}

\section{Mechanisms of Action, Efficacy and Side Effects of Nivolumab and Its Therapeutic Use at Itabashi Hospital, Nihon University School of Medicine}

\author{
Satoshi IzaKi, Koremasa Hayama and Tadashi Terui \\ Division of Dermatological Science, Department of Dermatology, Nihon University School of Medicine
}

\begin{abstract}
Malignant melanomas easily metastasize and are often resistant to conventional classical therapies, i.e., surgery, chemotherapy and radiotherapy, in patients with advanced/metastatic malignant melanoma. In recent years, rapid advances have been made in the immunotherapy of malignant melanoma. New medicines, which have been approved by Federal Drug Administration (FDA), have dramatically improved the clinical outcomes for patients with advanced/metastatic melanoma. Nivolumab is an immune checkpoint inhibitor that targets programmed cell death-1 (PD-1) receptors. PD-1 is expressed on many immune cells, including T cells, B cells and natural killer cells. Engagement of PD-1 with its ligands (PD-L1 and PD-L2) induces functional exhaustion of the cytotoxic immune response. Nivolumab inhibits the PD-1 pathway, and thus activates the cytotoxic immune response. Although the immune checkpoint inhibitor tends to take a few months until it exhibits efficacy, once established, the efficacy often lasts for a long time. However, immune checkpoint inhibitors can have many adverse effects, including autoimmune-related inflammation. In particular, relevant severe adverse effects include interstitial pneumonia, colitis, liver dysfunction, thyroid disorders, and infusion reaction. Other affected organs include the skin, eyes, kidneys and nerves. Furthermore, several cases of fulminant type 1 diabetes mellitus have been reported in 2015 and 2016. Because we cannot predict what kinds of adverse effects will occur or when they will occur, we must observe patients carefully in order to detect any adverse events early on, and initiate appropriate treatments. The development of a number of new therapies will provide benefits for patients with malignant melanoma. Dermatologists must use these new drugs appropriately after determining the correct diagnostic information and providing supporting evidence.
\end{abstract}

Key words: malignant melanoma, nivolumab, immune checkpoint inhibitor, PD-1, PD-L1 悪性黒色腫, 免疫チェックポイント阻害薬，ニボルマブ, PD-1, PD-L1

(J. Nihon Univ. Med. Ass., 2016; 75 (4): 156-160)

\section{はじめに}

悪性黒色腫は極めて遠隔転移を生じやすい悪性度の 高い腫瘍である. American Joint Committee on Cancer が 2001 年に発表した悪性黒色腫の TNM 分類と病期分類 に基づくと, 病期 IV の 5 年生存率は $13 \%$ である ${ }^{1)}$ ， そ のような進行期の悪性黑色腫に対する従来の治療法は, 原発巣, 遠隔転移巣とも切除可能な場合に扔ける外科的 切除や, 化学療法, 放射線療法といった集学的な治療が 主であった

代表的な化学療法はダカルバジン (DTIC) の単剤投 与であった. DTIC は 1970 年に発見され, 悪性黒色腫 に対する奏効率は 18〜20\%，完全奏効率は 5\% 以下で ある2)、その後，DTICを主体とした多剤併用療法が考 案されてきたが, DTIC 単剤との比較において survival benefit が認められた方法は一つもない状態であった3).

2011 年以降，悪性黒色腫に対する分子標的薬剤の開
発が目覚ましい進歩を遂げている。本稿ではその中で も，日本で世界に先駆けて承認されたニボルマブについ て概説する。

\section{I ． 新しい治療薬の出現}

2011 年 3 月に細胞傷害性 T リンパ球抗原 4 (cytotoxic T lymphocyte antigen 4, 以下 CTLA-4）に対する抗体 療法であるイピリムマブ（ヤーボイ@），2011 年 8 月 にBRAF 阻害薬であるべムラフェニブ（ゼルボラフ ®) がアメリカの Federal Drug Administration (FDA) で承認 された，さらに，2014年 7 月に世界に先駆けて日本で programmed cell death-1 (PD-1) に対する抗体療法である ニボルマブ（オプジーボ®）が承認された。これらは従 来の悪性黒色腫に対する化学療法よりも高い治療効果を 示す.

覀性黑色腫に対する新規薬剂は，腫瘍免疫の抑制分子 に対する抗体である免疫チェックポイント阻害薬と腫瘍 
細胞の増殖や転移に関わる変異分子を阻害する分子標的 薬に大きく分けられる。前者の免疫チェックポイント阻 害薬の範疇の薬劑がイピリムマブとニボルマブであり, 後者がベムラフェニブである。

\section{II．ニボルマブの作用機序}

ニボルマブは PD-1 に対するヒト型モノクローナル抗 体である。PD-1 は 1992 年に Ishida らによって T 細胞 の細胞死が誘導される際に発現する I 型膜蛋白質をコー ドする遺伝子としてクローニングされた4). その数年後 にPD-1ノックアウトマウスが作製され，PD-1ノック アウトマウスが外来抗原に対して過唾な抗体産生を起こ すことを示された ${ }^{5)}$ そそのノックアウトマウスを長期飼 育すると, 脾臓の腫大と自己抗体の産生を伴う糸球体腎 炎，関節炎などの自己免疫疾患を自然発症することがわ かった6). これらの結果から，PD-1 は末梢に拈免疫 寛容に強く関与していることが示唆された。

PD-1 は活性化後, 分化したエフェクター $\mathrm{T}$ 細胞, B 細胞や骨髄系免疫細胞などの免疫細胞に発現する CD28 ファミリーに属する受容体である。抗原提示細胞が提示 するリガンド (PD-L1 や PD-L2) がリンパ球に発現する この受容体に結合すると，抑制性シグナルが伝達され， 活性化が抑制される。これらのリガンドは卵巣癌，悪性 黒色腫, 食道癌, 腎細胞癌, 膵臓癌, 尿路上皮癌など 様々な癌組織に発現しており ${ }^{7)}$, その発現と術後の生存 期間には負の相関関係があることが報告されている これらの研究の結果から, 癌細胞が抗腫瘍免疫を回避 する機序の一つとして PD-1/PD-L1 経路が示唆された. その後, 抗 PD-1 抗体の開発が進められ, ニボルマブが 誕生した。Fig. 1 にニボルマブの作用機序を示す。悪性 黒色腫の患者においては，腫瘍細胞や腫瘍周囲組織に
も PD-L1 が発現している. PD-L1 と T 細胞に発現する PD-1の結合が，T細胞に負のシグナルを伝達して活性化 を抑制し, 癌細胞の腫瘍免疫からの逃避を引き起こす7). ニボルマブは PD-1 と PD-L1/PD-L2 の結合を阻害し, T 細胞への抑制性シグナルを減少させることで, 腫瘍免疫 反応を回復させる。

\section{III. ニボルマブの効果}

ニボルマブの国内での保険適用は，添付文書上では根 治切除不能な悪性黑色腫と, 切除不能な進行 - 再発の非 小細胞肺癌である。術後の再発や転移の予防目的に使用 することはできない，悪性黒色腫に対する実際の使用法 は, 化学療法未治療の場合には 1 回 $3 \mathrm{mg} / \mathrm{kg}$ を 2 週間隔 で点滴静注する。また, 化学療法既治療の場合には 1 回 $3 \mathrm{mg} / \mathrm{kg}$ を 2 週間隔，もしくは 1 回 $2 \mathrm{mg} / \mathrm{kg}$ を 3 週間隔 で点滴静注する. $3 \mathrm{mg} / \mathrm{kg}$ を 2 週間隔で投与する方法と $2 \mathrm{mg} / \mathrm{kg}$ を 3 週間隔で投与する方法の間に臨床効果や副 作用の大きな差はないとされている ${ }^{10)}$. ニボルマブによ る治療をいつまで続けるかを判断できるデー夕は存在せ ず，患者のリスク・ベネフィットに応じて判断すること となる.

国内での第 I 相試験 (ONO-4538-01) では 17 例の悪性 黒色腫患者が対象となった ${ }^{11)}$ ，その結果，17 例中 3 例 の PR (partial response) と 3 例の SD (stable disease) が確 認され，5例 (29\%) で 6 ケ月以上の効果持続が確認され た。また，35 例の進行期悪性黒色腫を対象とした国内 の第 II 相試験 ${ }^{10)}$ では奏効率は $23 \%$, 奏効期間中央值は 172 日であった。

免疫チェックポイント阻害薬では, 作用が出現する までに 2〜3 ケ月以上の期間を要することが多い. しか し，一度効果が出現するとその効果が長期間持続する特

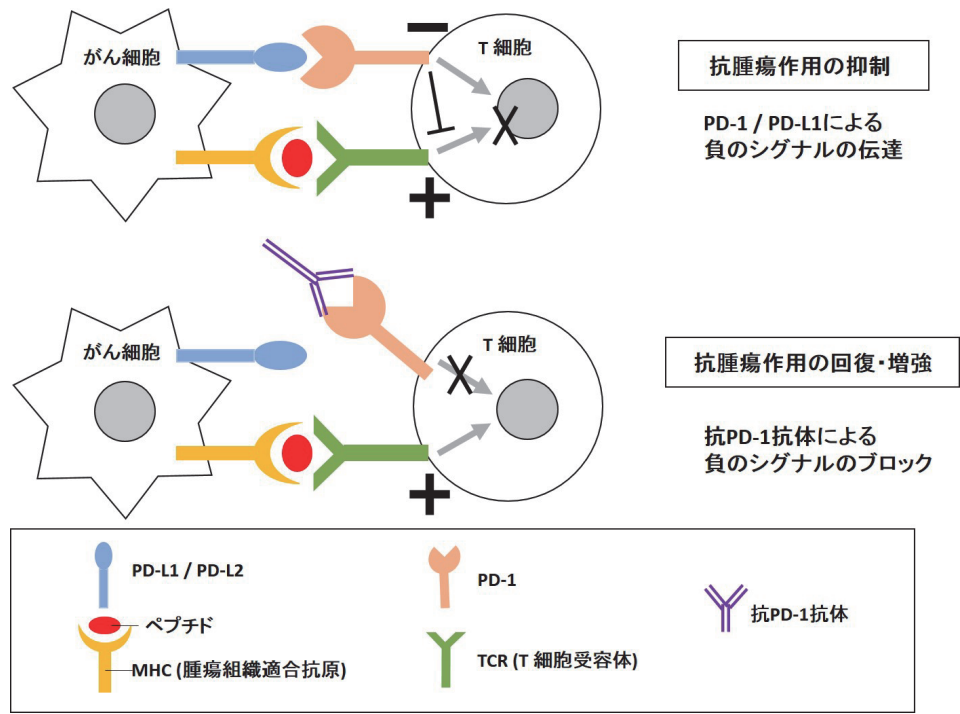

Fig. 1 Suppression of tumor immunity by PD-1 and release of the suppression by anti PD-1 antibody. (Excerption from references 10) 
徵がある。国内の第 II 相試験は，540日間の観察期間を 置いて評価している，PR までを含む奏効率は $23 \%$ であ るが，SD まで含めると $65.8 \%$ まで上昇し，半数以上の 患者で悪化が防がれていることが分かる ${ }^{10)}$. 治療の効果 判定には従来からの Response Evaluation Criteria In Solid Tumors (RECIST) が使われているが，腫瘤が増大傾向を 示した後に効果が発現する偽性増殖 (pseudo progression) を呈することがある ${ }^{10)}$. これは治療反応としての免疫

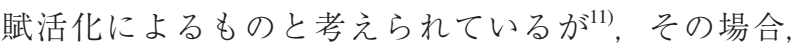
RECIST で判定すると progress disease (PD) となってし まう，免疫反応も考慮した新たな評価法のガイドライン が提案されており ${ }^{12)}$, 免疫療法における効果判定に対し て参考にされる場合がある。

\section{N. ニボルマブの副作用}

免疫チェックポイント阻害薬は, 免疫機構による抗腫 瘍効果を介して臨床効果を発揮する。そのため，副作用 の発現内容とパターンは従来の細胞傷害性化学療法とは 大きく異なり，自己免疫によると考えられる炎症性の副 反応がみられる ${ }^{10)}$. 国内第 II 相試験の日本人進行性悪性 黒色腫患者における観察では，有害事象がみられた患者 は30 例 (85.7\%), 薬剤関連の有害事象と判断された患 者は 16 例 $(45.7 \%)$ であった。最も高頻度に発現した薬 剂関連の有害事象は, FT3 減少, FT4 減少およびALP 増加であった ${ }^{13)}$. Grade 3/4の薬剤関連の有害事象の発 現率は 6 例 $(17.1 \%)$ であり, 最も高頻度に発現した有 害事象は， $\gamma$-GTP 増加 (4 例， 11.4\%), AST 増加 (2 例, $5.7 \%$ )，および CRP 増加 (1 例， $2.9 \%$ )であった ${ }^{13)}$ ，有害 事象の発現時期は一般的に治療開始後の最初の 6 ケ月間 であった14).

ニボルマブで特に注意すべき副作用は間質性肺炎, 大腸炎・下痢，肝機能障害 - 肝炎，甲状腺機能障害， infusion reactionである。これらが強くみられた場合は， 投与中止を検討し，適切な処置を行わなくてはならな い.また，新たな副作用として劇症 1 型糖尿病も報告さ れている。以下に各副作用が出現した際の注意点につい て述べる。

間質性肺炎：死亡に至った例も報告されている。呼吸 器症状として息切れ, 呼吸困難, 乾性咳嗽, 胸痛 (胸膜 炎, 胸水貯留), 喘鳴 (気道病変), 血痰 (肺胞出血) が ある。早期発見のために胸部 X 線検査や血清マーカー (KL-6，SP-A，SP-D)， $\mathrm{SpO}_{2}$ のモニタリング，患者状態 の観察を十分に行う必要がある。検査值や呼吸器症状の 異常がみられた場合は速やかに胸部 X 線, 胸部 CT, 特 に高分解能 CT (HRCT), 血清マーカー等の検査を実施 し, 必要に応じて呼吸器専門医と連携をとる。呼吸器

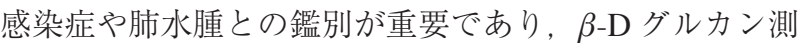
定，喀痰培養，喀痰からの細菌・抗酸菌・Pneumocystis jirovecii などの PCR や胸腔鏡下肺生検, 気管支肺胞洗浄
も考慮する。間質性肺炎が疑われた場合は速やかに投与 を中止し，副腎皮質ステロイドの投与等の適切な処置を 行う.

大腸炎・下痢：大腸炎，重度の下痢を起こすことがあ る。持続する腹痛，下痢，血便，タール便などがみられ た場合は精密検査を行い，投与中止を検討する．消化器 内視鏡が診断に有効であるため, 必要に応じて消化器専 門医と連携する。症状がひどい場合にはステロイド投与 を検討する，特に症状がひどい場合にはインフリキシマ ブの投与が必要となることもある。

肝機能障害・肝炎：AST 増加, ALT 増加, $\gamma$-GTP 増 加, ALP 増加等を伴う肝機能障害, 肝炎が出現するこ とがある。自覚症状として倦意感，眼球結膜黄染，嘔 気, 嘔吐, 食欲不振, 痋痒感, 黄疸がみられる。ニボル マブ投与前には，毎回肝機能検査值を確認する。異常が みられた場合は感染症，原疾患の進行，併用薬，アル コールなどの原因鑑別を行い, 必要に応じて消化器専門 医と連携をとる。ニボルマブによる肝機能障害・肝炎が 疑われた場合は投与を中止し，副腎皮質ステロイドの投 与等の適切な処置を行う。

甲状腺機能障害：機能低下症，六進症ともに出現する 可能性がある。機能低下症では倦总感, 浮腫, 寒がる, 動作や喋り方が緩慢になるなど, 機能充進症では多汗, 体重減少, 眼球突出, 甲状腺腫脹, 動悸, 振戦, 不眠な どがみられる。ニボルマブ投与前，投与中は定期的な TSH，FT3，FT4 等の測定を実施するが，大きな異常值 とならない軽症例も多い. 内分泌系の障害において副腎 機能低下や下垂体炎が起こることがあり，鑑別が必要な 場合は ACTH やコルチゾール測定を行うとともに，下 垂体撮影や MRI 撮影も考慮する。必要に応じて内分泌 専門医と連携をとる。ニボルマブによる甲状腺機能障害 が疑われる場合は，投与の減量，中止，ホルモン補充療 法を行う。下垂体炎では副腎皮質ステロイドの全身投与 も考慮する。

Infusion reaction：発熱，悪寒，瘙痒感，発疹，眼 瞼・舌·口唇の腫脹，高血圧，低血圧，動悸，呼吸困 難，咳，意識障害，めまい，嘔吐等の症状が出現するこ とがある。ニボルマブの投与中，投与後はバイタルサイ ンを測定し，患者の状態を十分に観察する。また 2 回 目以降の投与時に初めて重度の infusion reaction が発現 することもあるので，毎回患者の状態は十分に注意を払 う。異常がみられた場合は，まず注入速度を緩めるか中 止する。症状に応じて解熱鎮痛薬，抗ヒスタミン剤，副 腎皮質ステロイドなどの投与を行う。重度の場合は酸素 吸入，アドレナリン，気管支拡張薬，昇圧剤の投与等適 切な処置を行う. Infusion reactionがみられた患者には, 次回投与時からアセトアミノフェンやジフェンヒドラミ ン，場合によっては副婜皮質ステロイドをニボルマブ投 与前に予防的に投与する。 
劇症 1 型糖尿病：2016 年 1 月時点で 1 型糖尿病の副 作用が因果関係不明のものも含めて 7 例報告され，添 付文書にも重篤な副作用として追加された。そのうち劇 症 1 型糖尿病は 3 例である。 1 週間前後以内にケトアシ ドーシスに陥るなど急激に重篤化するおそれがあるので 注意が必要である。前駆症状として発熱，咽頭痛，上腹 部痛, 悪心・嘔吐が出現し, 糖尿病の症状として口渴, 多飲, 多尿, 体重減少, 全身倦总感, 意識障害が出現す る。症状が出現した場合は早期に血糖，尿ケトン体，尿 糖を含む検査を実施し，早期に診断する必要がある。1 型糖尿病が疑われる場合は，糖尿病専門医や内分泌専門 医と連携をとる.

その他：ほかに皮膚障害として瘙棒症, 白斑, StevensJohnson 症候群など，眼症状としてぶどう膜炎による急 速な視力低下，腎機能障害，神経障害などが起こる可能 性がある。重要な有害事象の診断とその対応は対処法の アルゴリズムを含む適正使用ガイドが製薬メーカーから 発行されているので参考にできる ${ }^{10)}$.

このような多様な有害事象が様々な時期に出現するた め，その発生を予測することは困難である。そのため副 作用の早期発見と適正な時期の臨床検査実施のために, 検査項目とそのスケジュールをあらかじめ決めておくと よい ${ }^{15)}$ ，患者の状態を常に把握し，有害事象に関連する 自覚症状を理解できるまで，患者本人のみならず家族も 含めて繰り返し説明することが重要である ${ }^{10)}$

\section{V. 当科での使用例}

当院で経験した症例をご紹介したい.

症例：43 歳, 女性.

既往歴：急性虫垂炎

現病歴：2007 年 9 月に当科を紹介受診した。腰部右 側に $40 \times 27 \times 20 \mathrm{~mm}$ の黑色，易出血性の結節があっ た。悪性黒色腫の診断で, 2007 年 10 月に悪性腫瘍切除 術兼分層植皮術を施行した. tumor thickness $6.25 \mathrm{~mm}$,
T4bNOM0, stage IIc であった。右鼠径リンパ節，右腋 窩リンパ節郭清を施行し，結果は陰性であった。 2007 年にDAV 療法を 2 コース，2008 年にDTIC 療法を 4 コース施行した。2014 年 11 月に胸部右側に結節が出現 した。 2015 年 1 月に切除した結果, 無色素性悪性黒色 腫と診断した。同月から嘔気が出現し改善なく, 腹部造 影 CT を施行したところ, 癌性腹膜炎が疑われ 2015 年 2 月に当科入入院した。

入院後経過：腹腔穿刺, CT, MRI の結果, 悪性黑色 腫の腹膜播種, 肺転移, 卵巣転移, 脳転移が疑われた。 外科的切除は不可能であり，2015 年 2 月からニボルマ ブを $2 \mathrm{mg} / \mathrm{kg}$ を 3 週間ごとに計 5 回使用した。投与開始 後の MRI や CT で, 脳転移からの脳出血, 脳転移巣 · 肺転移巣の増大がみられた。 2015 年 5 月から頻回の下 痢が出現し，二ボルマブによる有害事象の Grade 3 と 考え，水溶性プレドニンを $40 \mathrm{mg} /$ 日で投与した。症状 は軽快してきたため，7月に投与は終了した。2015 年 6 月にコーヒー残椬様の嘔吐があった。緊急内視鏡検査 の結果，上部消化管出血があり止血を行った。 経過中に 発熱, 誤嬹性肺炎, 真菌血症が出現し, 抗真菌剤, 抗菌 剤で治療したがコントロール不良であった。また，癌性 腹膜炎による腹水貯留が著明にあり，頻回の腹腔穿刺を 要した。 2015 年 6 月下旬に嘔気の増強がみられたため, 頭部 CT, MRI を施行したところ, 出血性脳転移の悪 化・新生が疑われた。2015 年 7 月に意識レベルの低下, 呼吸状態の悪化があり死亡した。

考察：ニボルマブは新しく開発された免疫チェックポ イント阻害薬の一つであり, DTIC 単剤との比較で全生 存期間の優越性が示されている ${ }^{16)}$ ，自験例は，根治切除 不能な第 IV 期，DTICによる治療歴あり，自己免疫疾 患の既往なし，とニボルマブを使用できる条件が揃って いた。しかし，投与開始後の検査で転移巣の腫瘍増大が みられ，それに伴う意識障害, 胸水・腹水貯留, 疼痛な どが出現していたことから，残念ながら効果がみられな

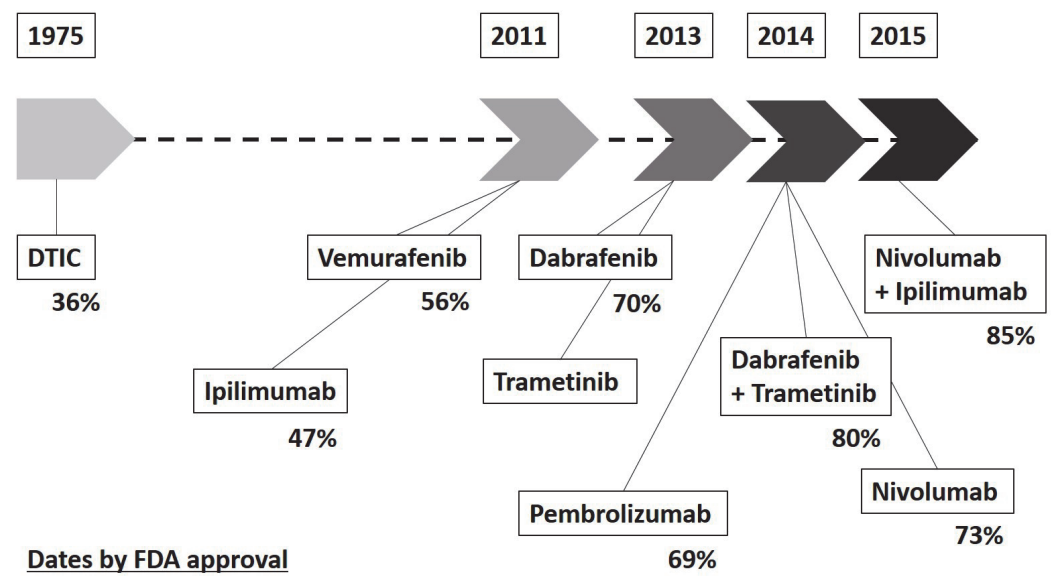

Fig. 2 Progression of 1 year survival rate in each drug therapy of malignant melanoma. (Excerption from references 3) 
かった症例と考える。

国内で適応のある悪性黒色腫に対する他の新規治療 薬として，イピリムマブやべムラフェニブがある。どち らも DTIC 単剤投与群と比較し有意に全生存期間を延長 するものである ${ }^{3)}$. Fig. 2 に進行期悪性黒色腫に対する 各薬剤の 1 年生存率を示す. DTIC が化学療法の主体で あった頃に比べ, 2011 年以降は革新的な進化を遂げて いることがわかる。 ニボルマブ，イピリムマブ，ベムラ フェニブの中ではニボルマブが最も 1 年生存率が高い. しかし，自験例において，その 3 剂のうちどれが最も効 果的であったかは不明である。薬剤選択に活用できるバ イオマーカーが発見されれば，各症例によって，より効 果的な治療を施すことが可能になると思われる。

覀性黒色腫を含む固形腫瘍組織での免疫組織学的検討 で，PD-L1 発現例のみに抗 PD-1 抗体の臨床効果があり, PD-L1 非発現例では臨床効果がなかったとする報告があ る ${ }^{17)}$.この報告は抗 PD-1 抗体療法において PD-L1 がバ イオマーカーとなりうることを示唆するが，これに反す る結果も報告されている ${ }^{10)}$ ，今後の検討が待たれる。

ニボルマブ使用後には自己免疫が関わる炎症性副反応 がみられることがある。自験例で明らかな自覚症状が出 現した有害事象は下痢であった。また，軽度の有害事象 として, AST, ALT の増加, TSH, FT4の増加, 白斑 がみられた。 上部消化管出血はニボルマブ投与と関連が あったかどうかは不明である。下痢は投与開始から 3 ケ 月後, AST, ALT, TSH の異常は 2 ケ月後, FT4 の異常 は 1 ケ月後, 白斑は 4 ケ月後に出現しており, 有害事象 出現の時期は様々なことが窺える。いつどのような有害 事象が出現するかを予測することは今のところ困難であ $る^{10)}$ ．副作用を早期に発見するためには定期的な血液検 査のモニタリング，問診，患者状態の観察が必要である と思われる。

有害事象が改善した後，ニボルマブによる治療を再開 することは可能である。しかし，ニボルマブによる治療 効果, 患者の全身状態を把握し, 患者およびその家族と 話し合いながら総合的に判断するべきであると思われる.

\section{おわりに}

数々の新規薬剂が出現したことにより，免疫チェック ポイント阻害薬と BRAF 阻害薬などのシグナル伝達阻 害薬をどのように選択もしくは組み合わせていくかが今 後の課題となる。 Larkin らはニボルマブ単独, ニボルマ ブとイピリムマブの併用の方が，イピリムマブ単独より も無増悪生存期間が有意に高かったとしている ${ }^{18)}$ 。また PD-L1 が陰性であった患者は, PD-1 阻害薬と CTLA-4 阻害薬を組み合わせたほうが, それぞれ単独よりも効果 的であるとしている ${ }^{18)}$. しかし，新たな薬凨の出現およ び併用による重篤な有害事象の増加や医療費の高騰など の問題点も指摘されている。新たに見つかった 1 型糖
尿病の副作用の出現は誰にも予測し得なかったものであ ろう。予測できないものに対しては，患者の状態を常に 観察し，わずかな変化も見逃さない覚悟で診療に臨むほ かはない。続々と出現する新規薬剤を有効に使うために は，最新の情報を収集し，科学的根拠に基づいた治療を 実施していかねばならない

\section{文献}

1) 斎田俊明。悪性黒色腫．最新皮膚科学体系 第 11 巻 母 斑・母斑症，悪性黒色腫 (玉置邦彦監)。中山書店，東 京, 2002; 226-246.

2) 並川健二郎, 山崎直也. Melanoma の化学療法. Skin Cancer 2009; 24: 497-503.

3）山崎直也. オーバービュー。皮膚臨床 $2015 ; \mathbf{5 7}$ 1639-1644.

4) Ishida $Y$, Agata $Y$, Shibahara K, et al. Induced expression of PD-1, a novel member of the immunoglobulin gene superfamily, upon programmed cell death. EMBO J 1992; 11: $3887-3895$.

5) Nishimura $\mathrm{H}$, Minato $\mathrm{N}$, Nakano $\mathrm{T}$, et al. Immunological studies on PD-1 deficient mice: implication of PD-1 as a negative regulator for B cell responses. Int Immunol 1998; 10: $1563-1572$.

6) Nishimura $\mathrm{H}$, Nose $\mathrm{M}$, Hiai $\mathrm{H}$, et al. Development of lupus-like autoimmune diseases by disruption of the PD-1 gene encoding an ITIM motif-carrying immunoreceptor. Immunity 1999; 11: 141-151.

7) Zou W, Chen L. Inhibitory B7-family molecules in the tumor microenvironment. Nat Rev Immunol 2008; 8: 467-477.

8) Thompson RH, Kuntz SM, Leibovich BC, et al. Tumor B7-H1 is associated with poor prognosis in renal cell carcinoma patients with long-term follow-up. Cancer Res 2006; 66: 3381-3385.

9) Hino R, Kabashima K, Kato Y, et al. Tumor cell expression of programmed cell death-1 ligand 1 is a prognostic factor for malignant melanoma. Cancer 2010; 116: 1757-1766.

10）鷂政大幾. ニボルマブ一効果と安全性について一。皮 膚臨床 2015; 57: 1647-1653.

11) 北園 聡, 山本 昇. 抗 PD- 1 抗体 ; 開発経緯と臨床効 果. 腫瘍内科 $2013 ; 11: 581-585$.

12) Wolchok J. How recent advances in immunotherapy are changing the standard of care for patients with metastatic melanoma. Ann Oncol 2012; 23 Suppl 8: viii15-21.

13) Deeks ED. Nivolumab: a review of its use in patients with malignant melanoma. Drugs 2014; 74: 1233-1239.

14) Topalian SL, Sznol M, McDermott DF, et al. Survival, durable tumor remission, and long-term safety in patients with advanced melanoma receiving nivolumab. J Clin Oncol 2014; 32: 986-988.

15) 宇原 久, 清原祥夫, 山崎直也. 抗 PD-1 抗体. Derma 2015; 230: 54-62.

16) Robert C, Long GV, Brady B, et al. Nivolumab in previously untreated melanoma without BRAF mutation. $N$ Engl $J$ Med 2015; 372: 320-330.

17) Wolchok JD, Kluger H, Callahan MK, et al. Nivolumab plus ipilimumab in advanced melanoma. $N$ Engl $\mathrm{J}$ Med 2013; 369: 122-133.

18) Larkin J, Chiarion-Sileni V, Gonzalez R, et al. Combined Nivolumab and Ipilimumab or Monotherapy in Untreated Melanoma. N Engl J Med 2015; 373: 23-34. 